\title{
Decision Making in Selecting Mobile Payment Systems
}

\author{
https://doi.org/10.3991/ijim.v13i09.10834 \\ Wornchanok Chaiyasoonthorn \\ King Mongkut's Institute of Technology, Ladkrabang, Thailand \\ Wornchanok.ch@kmitl.ac.th
}

\begin{abstract}
Thailand is transforming its economy into a digital economy. Mobile payment (m-payment) is a core technology that helps the country phases from the manufacturing-based economy into the digital economy. However, a question remains what factors influencing people to adopt mobile payment. Little literature focuses on users in Thailand. This study aims to determine factors associating with the decision-making process in selecting m-payment systems of respondents in Bangkok. The study addresses a research question. What do factors segregate m-payment adoption? 820 respondents were asked by using a questionnaire. Employment of confirmatory factor analysis (CFA) developed the measurement showing acceptable validity and reliability. The study uses multinomial logistic regression to classify Technology Choices (TCs). The results show low values of Pseudo R-Square, indicating that there is a lack of practical variables. Discussions and suggestions are addressed in this research.
\end{abstract}

Keywords-Decision making, Technology adoption, Consumer behaviour, End-user behaviour, Intention to use, Mobile payment, M-payment, Thailand.

\section{$1 \quad$ Introduction}

As a member of the Association of Southeast Asian Nations (ASEAN), Thailand is attempting to connect its e-payment systems with other members. Thailand used a digital push strategy to boost the usage of e-payment and m-payment systems. As a plan to reduce banknotes, the government promotes the use of mobile and internet banking increasing more than $140 \%$ from 2012 to 2016 [1].

M-payment systems benefit both government and citizen. The Thai government saves money from printing paper money, whereas the citizens are convenient to pay anywhere and anytime. Moreover, Thai merchants can be global traders using an mpayment system to receive cash from shoppers internationally. The goal of the Thai government is to develop a cashless payment system as well as to boost electronic commerce (e-commerce) transactions [2]. Electronic Transactions Development Agency [3] estimated that in 2017 the e-commerce transactions would rise to 2,812 billion baht (around $\$ 85.2$ billion: 33 Baht per USD) or almost 10 percent increase when compared with 2016. This increase in e-commerce transaction would lead to the rise in m-payment transactions. For example, the Bank of Thailand shows that the 
adoption of internet banking, mobile banking, electronic money has increased by 983 , 553, and 506 percent respectively between 2010 and 2016 [4].

However, to promote the effective use of m-payment systems, the understandings of perceived trust, privacy concern, and perceived risk are crucial. These factors significantly determine the use of m-payment systems [5]-[11]. In Information Systems, UTAUT2 is one of the most modern theory, explaining the use of consumer technology [12]. UTAUT2 does not incorporate trust, risk, and privacy concern into the model.

Users do not need to use a single technology to perform all tasks. Instead, they can select a wide range of Technology Choices based on the context of their use. Each technology channel has different levels of trust, privacy concern, and risk. These conditions potentially determine the use of consumer technologies such as m-payment systems.

Therefore, this research aims to determine factors associating with the decisionmaking process in selecting an m-payment system of respondents in Bangkok, Thailand. The study addresses a research question: What do factors segregate m-payment adoption? Our research contribution is a statistical model for explaining the selection of different technology adoption.

\section{$2 \quad$ Literature Review}

Little research has been done to understand how users select different technologies depending on their contexts. Hernandez and Mazzon [13] showed a possibility to use behavioral theories to understand technologies selections. They used the diffusion of innovation (DoI) [14], the theory of planned behavior (TPB) [15], and the technology acceptance model (TAM) [16]. However, these theories are old. Besides, Information Systems researchers have developed Unified Theory of Acceptance and Use of Technology 1\&2 (UTAUT 1\&2) [11], [12], [17], which are more contemporary theories. Therefore, I decided to apply UTAUT2 for testing the applicability of a new theory.

Unified Theory of Acceptance and Use of Technology (UTAUT) aims to fix the problem of TAM because TAM has a lack of other possible factors associated with the phenomenon being explained. Besides, TAM constructs are too similar to other theories. For example, the relative advantage of DoI is similar to perceived usefulness. Hence, applying only TAM can misguide developers in the wrong direction $[18, \mathrm{p}$. 217]. New constructs are added in UTAUT2; these constructs are habit, facilitating conditions, and hedonic motivation. Furthermore, moderating factors are added in UTAUT2. These moderators are gender, age, and experience [12], [17].

\subsection{Prior studies}

Table 1 shows research conducted in the past and relationships associated with TAM. However, few studies have used UTAUT2 as the research framework. 
Table 1. The Summary of Relationships between Independent and Dependent Variables

\begin{tabular}{|l|l|c|}
\hline \multicolumn{1}{|c|}{ IV } & \multicolumn{1}{c|}{ DV } & Reference \\
\hline Usefulness & Use behavior & {$[19]$} \\
\hline Ease of Use & Usefulness & {$[18],[20]$} \\
\hline Ease of Use & Intention & {$[21]$} \\
\hline Relative Advantage & Intention & {$[18]$} \\
\hline Compatibility & Intention & {$[18],[21]$} \\
\hline Trial-ability & Intention & {$[18]$} \\
\hline Voluntariness & Intention & {$[18]$} \\
\hline Innovativeness & Intention & {$[8]$} \\
\hline Innovativeness & Usefulness & {$[22]$} \\
\hline Innovativeness & Ease of use & {$[22]$} \\
\hline Perceived value & Intention & {$[9],[10]$} \\
\hline Risk & Intention & {$[7],[8],[10],[23]$} \\
\hline Trust & Intention & {$[7]$} \\
\hline Usefulness & Trust & {$[7]$} \\
\hline Ease of use & Trust & {$[6],[9],[25],[26]$} \\
\hline Security & Trust & {$[6],[9]$} \\
\hline Privacy concern & Trust & {$[27]$} \\
\hline Innovativeness & Risk & {$[28]$} \\
\hline Innovativeness & Trust & {$[9]$} \\
\hline Trust & Value & \\
\hline & & $[21]],[2]$ \\
\hline
\end{tabular}

The conceptual framework consists of Behavioral Intention (BI), Performance Expectancy (PE), Effort Expectancy (EE), Facilitating Conditions (FC), Social Influence (SI), Price value (PV), Hedonic Motivation (HM), and Habit (Ha). In addition to UTAUT2' constructs, I decided to add Personal Innovativeness (PI), Perceived Trust (PT), Perceived Risk (PR), and Privacy Concern (PC) based on prior studies.

Figure 1 shows the conceptual framework adapted from Venkatesh et al. [12] and Hernandez and Mazzon [13].

TC refers to modes of technology that users use for paying e-money. TC was first used in adoption research by K. K. Kim \& Prabhakar [29], referring to different modes of technology usage.

$\mathrm{BI}$ refers to the degree to which people intend to perform a technology [30]. BI explains UB [12]. BI is an intermediate construct connecting UB and other attitudinal constructs [15].

PE represents the perception of users; they think that using a particular technology brings benefits to them [12]. PE can be an attitudinal construct, especially cognitive information [15], [31]. Besides, PE can be viewed as extrinsic motivation [32], [33].

EE refers to the extent to which customers view that a particular m-payment system is easy to use [17]. Successful technologies should not create confusion for their users when the users want to use.

FC refers to the degree to which a user of an m-payment system thinks that he or she has technological infrastructure supports the use of m-payment system [17]. This construct is similar to compatibility and perceived behavioral control [14], [15], [17], [34]. 


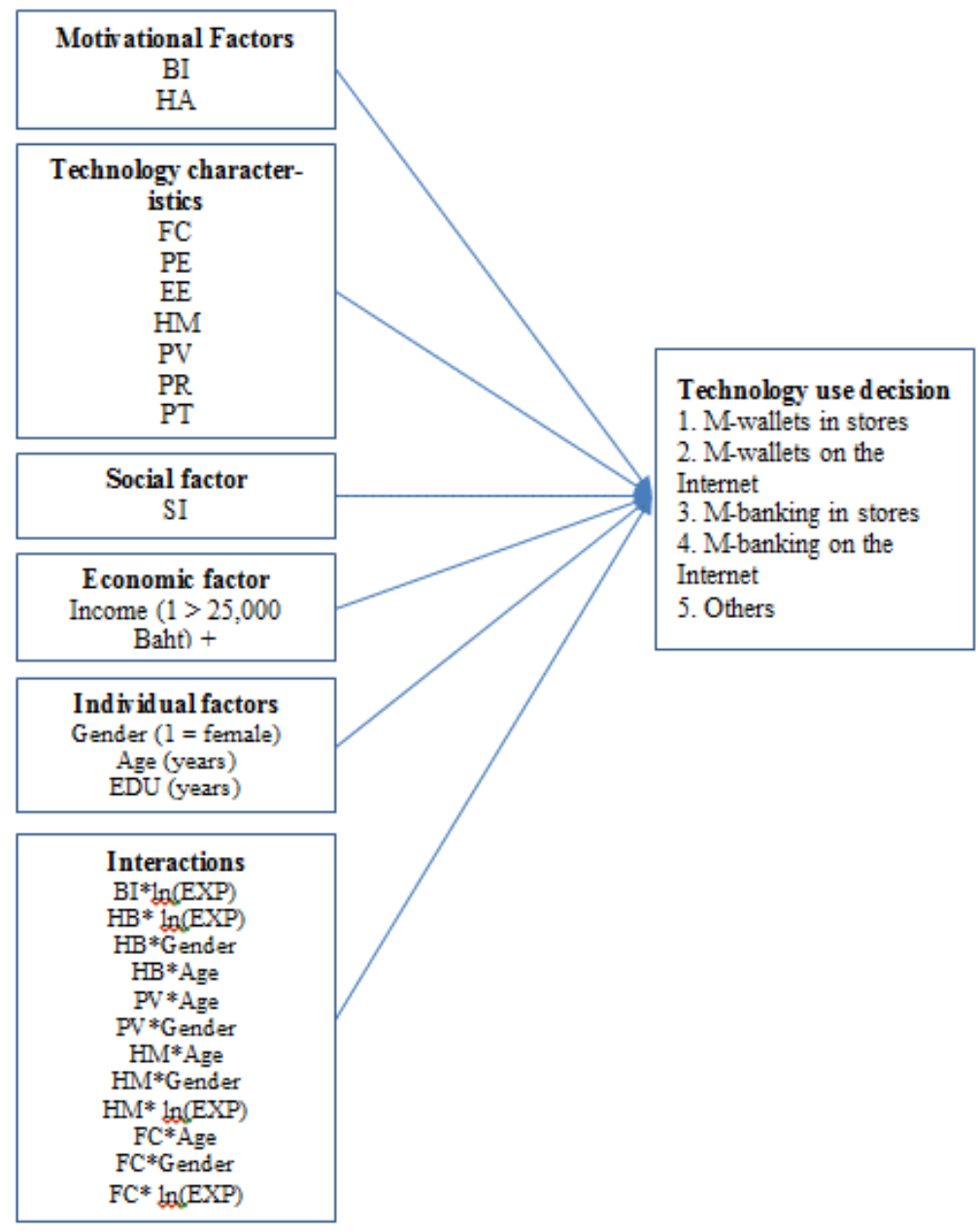

Fig. 1. The conceptual framework

SI means the degree to which the use of an m-payment system believes that important people think that he or she should or should not use such an m-payment system [17]. Society can help to expedite the rate of technology adoption.

PV is a construct introduced to explain adoption behavior. Consumers weight the benefits that they obtain to cost that they pay [12]. Like PE, price value is used to describe BI. M-payment can have a transaction cost. Hence, this construct is appropriate for this study.

HM refers to the degree of fun, enjoyment, happiness when the user uses a particular technology [12]. HM significantly positively affects BI in many technologies such as learning management software [35], social media [36], and e-commerce [37]. 
Ha refers to the degree that the user of an m-payment system think that he or she uses the technology as their habit. Ha influences the UB and BI of users [12]. A study shows that Ha affects both BI and UB regarding mobile banking [38].

PI is a construct that has been introduced by Rogers [14]. People who have innovativeness adopt new technology rapidly than people who have less innovativeness [14]. PI has a significant impact on BI to use information technology [8].

PT can be viewed as confidentiality, integrity, authentication, of the m-payment system [6]. PT enhances the attitudes of users to become confident with the mpayment system which in turn declines the uncertainty [7], [11].

PT may be related to technological parts of the m-payment systems. PR shows that people decline the rate of adoption regarding risk technology such as e-commerce and m-payment. PR can be viewed as the costs of technology adoption [5]. Rakhi and Mala [8] include PR as the same construct as privacy risk and financial risk. Studies show that PR negatively influence BI [8], [10].

PC shows how much users trust a system. Customers feel that their information perhaps is misused by electronic services such as e-commerce and m-payment companies and systems [6], [9].

\section{$3 \quad$ Methodology}

The author employed a self-reported paper-based questionnaire. The attitudinal measurement in this study consisted of a seven-point bipolar semantic differential scale from strongly disagree (1) to strongly agree (7) since this scale can be assumed as a numerical scale, unlike a Likert scale. The respondents were asked what the most recently used technology channel was. Table 2 shows the measurement of attitudinal constructs.

Table 2. The Measurement of Attitudinal Constructs

\begin{tabular}{|c|c|c|c|}
\hline Constructs & Items & Description & Reference \\
\hline \multirow{4}{*}{$\mathrm{BI}$} & BI1 & I intend to use this mobile payment continuously in the future. & \multirow{4}{*}{$\begin{array}{l}\text { (Fishbein and } \\
\text { Ajzen, 2010; } \\
\text { Venkatesh et al. } \\
\text { 2003, 2012) }\end{array}$} \\
\hline & $\mathrm{BI} 2$ & I attempt to use this mobile payment in everyday life. & \\
\hline & $\mathrm{BI} 3$ & I plan to use this mobile payment often. & \\
\hline & BI4 & I expect to use this mobile payment continuously. & \\
\hline \multirow{4}{*}{$\mathrm{PE}$} & PE1 & I find that this mobile payment is useful in my life. & \multirow{4}{*}{$\begin{array}{l}\text { (Venkatesh et } \\
\text { al., 2003, 2012) }\end{array}$} \\
\hline & PE2 & Using this mobile payment makes my work accomplishes quickly. & \\
\hline & PE3 & Using this mobile payment increases the efficiency of my work. & \\
\hline & PE4 & Using this mobile payment makes me work faster and save my costs. & \\
\hline \multirow{4}{*}{$\mathrm{EE}$} & EE1 & Learning how to use this mobile payment is easy for me. & \multirow{4}{*}{$\begin{array}{l}\text { (Venkatesh et } \\
\text { al., 2003, 2012) }\end{array}$} \\
\hline & EE2 & Using this mobile payment is clear and understandable. & \\
\hline & EE3 & I find that using this mobile payment is easy. & \\
\hline & EE4 & I find that it is easy to be an expert in using this mobile payment. & \\
\hline \multirow{3}{*}{ SI } & SI1 & $\begin{array}{l}\text { People who are important to me think that I should use this mobile } \\
\text { payment. }\end{array}$ & \multirow{3}{*}{$\begin{array}{c}\text { (Fishbein and } \\
\text { Ajzen, 2010; } \\
\text { Venkatesh et al., } \\
\text { 2003, 2012) }\end{array}$} \\
\hline & SI2 & $\begin{array}{l}\text { People who influence my behaviour think that I should use this mo- } \\
\text { bile payment. }\end{array}$ & \\
\hline & SI3 & $\begin{array}{l}\text { People whose opinions I like think that I should use this mobile } \\
\text { payment. }\end{array}$ & \\
\hline
\end{tabular}


Paper-Decision Making in Selecting Mobile Payment Systems

\begin{tabular}{|c|c|c|c|}
\hline Constructs & Items & Description & Reference \\
\hline & SI4 & $\begin{array}{l}\text { People whom I respect and admire encourage me to use this mobile } \\
\text { payment. }\end{array}$ & \\
\hline \multirow{4}{*}{$\mathrm{FC}$} & FC1 & I have enough resources to use this mobile payment. & \multirow{4}{*}{$\begin{array}{l}\text { (Venkatesh et } \\
\text { al., 2003, 2012) }\end{array}$} \\
\hline & FC2 & I have enough knowledge to use this mobile payment. & \\
\hline & FC3 & This mobile payment is compatible with other technologies I use. & \\
\hline & FC4 & $\begin{array}{l}\text { I often get support from other people when I have a problem using } \\
\text { this mobile payment. }\end{array}$ & \\
\hline \multirow{4}{*}{$\mathrm{HM}$} & HM1 & Using this mobile payment is fun. & \multirow{4}{*}{$\begin{array}{l}\text { (Venkatesh et } \\
\text { al., 2012) }\end{array}$} \\
\hline & HM2 & Using this mobile payment makes me happy. & \\
\hline & HM3 & Using this mobile payment is entertaining. & \\
\hline & HM4 & I feel happy when I use this mobile payment. & \\
\hline \multirow{4}{*}{$\mathrm{Ha}$} & Ha1 & Using this mobile payment is my habit. & \multirow{4}{*}{$\begin{array}{l}\text { (Venkatesh et } \\
\text { al., 2012) }\end{array}$} \\
\hline & $\mathrm{Ha} 2$ & I feel addicted to using this mobile payment. & \\
\hline & $\mathrm{Ha} 3$ & I must use this mobile payment often. & \\
\hline & $\mathrm{Ha} 4$ & Using this mobile payment becomes my normal routine. & \\
\hline \multirow{3}{*}{ PV } & PV01 & Expenses occurring from this mobile payment are reasonable. & \multirow{3}{*}{$\begin{array}{l}\text { (Venkatesh, } \\
\text { Thong and } \mathrm{Xu} \text {, } \\
\text { 2012) }\end{array}$} \\
\hline & PV02 & Using this mobile payment is worthy when compared with costs. & \\
\hline & PV03 & When compared with costs, this mobile payment creates value. & \\
\hline \multirow{4}{*}{ PR } & PR01 & Using this mobile payment brings risk to me. & \multirow{4}{*}{$\begin{array}{l}\text { (Chellappa and } \\
\text { Pavlou, 2002; } \\
\text { Rakhi and Mala, } \\
\text { 2014; Yang et } \\
\text { al., 2015) }\end{array}$} \\
\hline & PR02 & Using this mobile payment tends to make me lose. & \\
\hline & PR03 & Using this mobile payment is uncertain. & \\
\hline & PR04 & Using this mobile payment has the potential to bring financial loss. & \\
\hline \multirow{4}{*}{ TR } & TR01 & This mobile payment is trustworthy. & \multirow{4}{*}{$\begin{array}{c}\text { (Flavián and } \\
\text { Guinalíu, 2006; } \\
\text { Roca, García } \\
\text { and de la Vega, } \\
\text { 2009) }\end{array}$} \\
\hline & TR02 & The company that provides this mobile payment is trustful. & \\
\hline & TR03 & This mobile payment is faithful. & \\
\hline & TR04 & I trust this mobile payment. & \\
\hline \multirow{4}{*}{$\mathrm{PC}$} & PC01 & I worry that my personal information can be misused. & \multirow{4}{*}{$\begin{array}{c}\text { (Flavián and } \\
\text { Guinalíu, 2006; } \\
\text { Bonsón Ponte, } \\
\text { Carvajal-Trujillo } \\
\text { and Escobar- } \\
\text { Rodríguez, } \\
\text { 2015). }\end{array}$} \\
\hline & PC02 & I worry that my personal information can be sold and exchanged. & \\
\hline & $\mathrm{PC} 03$ & $\begin{array}{l}\text { I worry that my personal information can be used without my permis- } \\
\text { sion. }\end{array}$ & \\
\hline & $\mathrm{PC} 04$ & $\begin{array}{l}\text { I worry that my personal information can be collected, tracked, and } \\
\text { analyzed. }\end{array}$ & \\
\hline \multirow{4}{*}{ PI } & PI01 & If I hear the news about new technology, I will try quickly. & \multirow{4}{*}{ (Rogers, 1983) } \\
\hline & PI02 & I am the first person who tries new technology. & \\
\hline & PI03 & I like to try new technology. & \\
\hline & PI04 & I like to exploit new ideas. & \\
\hline
\end{tabular}

In addition to the attitudinal constructs, I measured experience (EXP) of users in the number of years. The natural logarithm was used to transform experience into a linear scale $(\ln (\mathrm{EXP}))$. Age is in the number of years. Education is also the number of years. Gender is 0 for males and 1 for female. Income is 0 for people who earn 25,000 Baht (about \$ 808.45) a month or lower and 1 for people who earn more than 25,000 Bath a month.

All attitudinal constructs here were tested by using confirmatory factor analysis (CFA). The reliability was measured by using Cronbach's Alpha and composite reliability. The acceptable value is more than 0.70 [39]. Regarding construct validity, the standardized factor loading should be higher than 0.70 and the average variance extracted (AVE) should be higher than 0.50 [39]. To satisfy the discriminant validity, 
the comparison between AVEs and the squared correlation between two constructs is used to investigate whether or not the constructs are different [39]. SPSS and Amos were analytical tools in this research.

\section{$4 \quad$ Results}

The sample size is 820 respondents. 397 (48.4 percent) are males, and 423 (51.6 percent) are female. Table 3 shows the distribution of cases of Technology Choices. There are six classes: 1) (using) m-wallets in physical stores, 2) m-wallets on the Internet, 3) m-banking in physical stores, 4) Mobile banking, and 5) other choices. The 'others' class is used as a reference. These classes reflect the most recently used technology choices (TC).

Table 3. The Group Information

\begin{tabular}{|l|c|c|}
\hline \multicolumn{1}{|c|}{ Technology Choices } & Number & Percentage \\
\hline 1) $m$-wallets in physical stores & 232 & $28.3 \%$ \\
\hline 2) m-wallets on the internet & 106 & $12.9 \%$ \\
\hline 3) m-banking in physical stores & 100 & $12.2 \%$ \\
\hline 4) m-banking on the internet & 80 & $9.8 \%$ \\
\hline 5) Mobile banking & 111 & $13.5 \%$ \\
\hline 6) others & 191 & $23.3 \%$ \\
\hline
\end{tabular}

Our initial findings show indices of Pseudo R-Square: Cox and Snell (.355), Nagelkerke (.367), and McFadden (.128). Likelihood Ration Tests were performed. The variable that has the highest $p$-value was removed, and then Likelihood Ratio Tests were performed again. I removed the following variables: $\mathrm{HM} *$ Age, $\mathrm{PV} *$ Age, PV*Gender, FC*Gender, PR, FC, EE, SI, HB*Gender, BI, HM, EDU, PE, PI, HB, $\mathrm{PV}, \mathrm{TR}, \mathrm{HM}^{*} \ln (\mathrm{EXP}), \mathrm{HB}^{*} \mathrm{Ln}(\mathrm{EXP}), \mathrm{HB}^{*}$ Age, HM*Gender, and Gender respectively. Table 4 shows the log-likelihood value, which is a measure of selecting independent variables identical to stepwise regression [39].

After I removed the non-significant variables, I obtained the values of Pseudo RSquare: Cox and Snell (.214), Nagelkerke (.224), and McFadden (.070). These values of Pseudo R-Square show the assessments of overall model fit. Of practical importance, these indices show low scores [39].

Table 4. The Likelihood Ratio Tests

\begin{tabular}{|l|c|c|c|c|}
\hline \multicolumn{1}{|c|}{ Effect } & $\mathbf{- 2}$ Log Likelihood of Reduced Model & Chi-Square & df & Sig. \\
\hline Intercept & 2604.757 & 16.209 & 5 & 0.006 \\
\hline Age & 2614.094 & 25.547 & 5 & 0.000 \\
\hline Income & 2633.563 & 45.015 & 5 & 0.000 \\
\hline BI*Ln (EXP) & 2610.299 & 21.751 & 5 & 0.001 \\
\hline FC*Age & 2653.459 & 64.911 & 5 & 0.000 \\
\hline FC*Ln (EXP) & 2633.227 & 44.679 & 5 & 0.000 \\
\hline
\end{tabular}


Table 4 shows the outcome after I terminated non-significant variables as mentioned before. The results are age, income, and the interactions between BI and $\ln$ (EXP), between FC and age, and between FC and $\ln (\mathrm{EXP})$.

Table 5. The Parameter Estimate

\begin{tabular}{|c|c|c|c|c|c|c|c|}
\hline \multicolumn{2}{|c|}{ Technology Choices } & B & $\begin{array}{l}\text { Std. } \\
\text { Error }\end{array}$ & Wald & df & Sig. & $\operatorname{Exp}(B)$ \\
\hline \multirow{6}{*}{ M-wallets in stores } & Intercept & -1.217 & 0.397 & 9.395 & 1 & 0.002 & \\
\hline & Age & -0.021 & 0.015 & 1.888 & 1 & 0.169 & 0.979 \\
\hline & Income & 0.949 & 0.237 & 16.028 & 1 & 0.000 & 2.583 \\
\hline & $\mathrm{BI} * \operatorname{Ln}(\mathrm{EXP})$ & 0.185 & 0.058 & 10.101 & 1 & 0.001 & 1.203 \\
\hline & FC*Age & 0.019 & 0.003 & 32.011 & 1 & 0.000 & 1.019 \\
\hline & $\mathrm{FC}^{*} \ln (\mathrm{EXP})$ & -0.320 & 0.070 & 21.103 & 1 & 0.000 & 0.726 \\
\hline \multirow{6}{*}{ M-wallets on the internet } & Intercept & -0.870 & 0.488 & 3.186 & 1 & 0.074 & \\
\hline & Age & -0.041 & 0.020 & 4.321 & 1 & 0.038 & 0.959 \\
\hline & Income & 0.723 & 0.287 & 6.338 & 1 & 0.012 & 2.062 \\
\hline & $\mathrm{BI}^{*} \ln (\mathrm{EXP})$ & 0.116 & 0.076 & 2.327 & 1 & 0.127 & 1.123 \\
\hline & FC*Age & 0.021 & 0.004 & 28.484 & 1 & 0.000 & 1.021 \\
\hline & $\mathrm{FC}^{*} \ln (\mathrm{EXP})$ & -0.364 & 0.087 & 17.705 & 1 & 0.000 & 0.695 \\
\hline \multirow{6}{*}{ M-banking in stores } & Intercept & -0.310 & 0.509 & 0.370 & 1 & 0.543 & \\
\hline & Age & -0.039 & 0.020 & 3.694 & 1 & 0.055 & 0.962 \\
\hline & Income & 0.506 & 0.298 & 2.888 & 1 & 0.089 & 1.658 \\
\hline & $\mathrm{BI} * \ln (\mathrm{EXP})$ & 0.197 & 0.075 & 6.972 & 1 & 0.008 & 1.218 \\
\hline & FC*Age & 0.014 & 0.004 & 13.478 & 1 & 0.000 & 1.014 \\
\hline & $\mathrm{FC}^{*} \ln (\mathrm{EXP})$ & -0.406 & 0.088 & 21.254 & 1 & 0.000 & 0.666 \\
\hline \multirow{6}{*}{ M-banking on the internet } & Intercept & 0.594 & 0.645 & 0.848 & 1 & 0.357 & \\
\hline & Age & -0.088 & 0.027 & 10.800 & 1 & 0.001 & 0.916 \\
\hline & Income & 1.773 & 0.316 & 31.550 & 1 & 0.000 & 5.891 \\
\hline & $\mathrm{BI} * \operatorname{Ln}(\mathrm{EXP})$ & -0.068 & 0.094 & 0.529 & 1 & 0.467 & 0.934 \\
\hline & FC*Age & 0.014 & 0.004 & 10.826 & 1 & 0.001 & 1.015 \\
\hline & $\mathrm{FC}^{*} \ln (\mathrm{EXP})$ & -0.209 & 0.101 & 4.271 & 1 & 0.039 & 0.812 \\
\hline \multirow{6}{*}{ Mobile banking } & Intercept & -0.363 & 0.510 & 0.506 & 1 & 0.477 & \\
\hline & Age & -0.091 & 0.023 & 14.961 & 1 & 0.000 & 0.913 \\
\hline & Income & 0.095 & 0.301 & 0.100 & 1 & 0.752 & 1.100 \\
\hline & $\mathrm{BI} * \ln (\mathrm{EXP})$ & 0.238 & 0.077 & 9.668 & 1 & 0.002 & 1.269 \\
\hline & FC*Age & 0.029 & 0.004 & 47.491 & 1 & 0.000 & 1.029 \\
\hline & $\mathrm{FC}^{*} \ln (\mathrm{EXP})$ & -0.474 & 0.087 & 29.628 & 1 & 0.000 & 0.623 \\
\hline
\end{tabular}

Note: The 'Others' class (Other types of m-payment systems) is the reference group.

As I can see from table 5, customers who use m-wallets in stores are those who have a high income. The more income that they have, the more likely they use mwallets in stores. Other factors are found in forms of interactions. The findings show that the interaction between BI and $\ln$ (EXP) and the interaction between FC and age help to classify consumers who use m-wallets in a physical store with positive directions. The interaction between FC and $\ln$ (EXP) shows a negative direction, suggesting that consumers who have both high FC and $\ln$ (EXP) tend not to use m-wallets in stores.

Considering using m-wallets on the Internet, customers who choose this channel tend to be young people rather than older people (negative relationship with age). 
Income is a positive classifier. Higher income consumers tend to use m-wallets on the Internet more than those who have lower income. The interaction between $\mathrm{FC}$ and age shows that people who have both high FC and age tend to use credit care on the internet. The interaction between FC and $\ln$ (EXP) shows a negative relationship with the using credit card on the Internet.

Concerning using m-banking in stores, both age and income do not have capabilities to classify users who use m-banking in stores. However, three interaction effects can classify users who use m-banking in stores. Users who have high both BI and ln (EXP) and users who have high both FC and age tend to use m-banking in stores, while the opposite trend is the users who have high both FC and ln (EXP); these users do not tend to use m-banking in physical stores.

In terms of using m-banking on the Internet, young users tend to use m-banking on the Internet more than older users. Income is a positive factor showing that the rich tend to use m-wallets on the Internet more than the poor do. The interaction effect between FC and age shows a positive relationship, suggesting that users who have high both FC and age tend to use m-banking on the Internet more than those who have low both FC and age. The interaction between FC and ln (EXP) shows a negative relationship. Users who have high both FC and $\ln (\mathrm{EXP})$ tend not to use $\mathrm{m}$-banking on the Internet.

Regarding internet banking, the finding suggests that age is a negative classifier. Older users tend not to use internet banking while young users manage to do so. The interaction effect between BI and ln (EXP) shows that users who have high both BI and $\ln (\mathrm{EXP})$ tend to use the internet banking more than those who have low both BI and $\ln (\mathrm{EXP})$. Likewise, the interaction between FC and age shows that users who have high both FC and age tend to use the internet baking more than those who have low both FC and age. The interaction between FC and ln (EXP) shows a negative relationship. Those who have high both FC and $\ln$ (EXP) tend not to use internet banking while those who have low both FC and ln (EXP) tend to use Internet Banking.

\section{Discussion}

The applicability of UTAUT2 [12] in technology classification is not apparent. Since UTAUT2 is a social science theory, it does not consider economic variables such as income. This study suggests that income is the most influential variable, for almost technologies except Internet banking, helping the decision making of users in selection m-payment systems. On the other hand, BI, which is the most utilized variable in social science, shows little effects on TC. TC tends to rely on socio-economic statuses, such as age and income. Although UTAUT2 constructs able to improve the classification of TC are BI and FC, both constructs are forms of interactions, not directly segregating TC. The evidence is the set of the values of Pseudo R-Square.

However, UTAUT2 predicts two moderators correctly. The interaction between FC and $\ln (\mathrm{EXP})$. Ln (EXP) moderates/interacts the path between FC and BI. Then I expected to find strong technology adoption of a technology channel for novice users 
who have high FC. In addition to $\ln (\mathrm{EXP})$, age moderates the path between FC and BI. I expected to find strong technology adoption of a technology channel for older users who have high FC. Hence, the findings support Venkatesh et al.[12]. I did not find significant evidence of gender.

The roles of PT, PR, and PC are not significant for users to change the modes of technology usage. This research has not found any support for PT, PR, and PC for technology classification. Studies have supported the uses of PR [7], [8], [10], [23], PT [9], [10], [21], [23], and [6], [9] in adoption research. However, these constructs are not capable of classifying different types of technology usage. This finding is consistent with that of Hernandez and Mazzon [13], showing that security and privacy are not capable of classifying three classes of banking users: 1) Internet/non Internet banking users, 2) non-internet users/ non-internet banking users, and 3) internet banking users.

Unlike Hernandez and Mazzon [13] who showed that income was not a significant classifier in the context of Internet banking, our research shows that income is essential for Thai m-payment users. Another inconsistency issue with Hernandez and Mazzon [13] is that their study showed a significance of education while our research has not found education important. This might be based on the purchasing power that might be different between the respondents of this study and Hernandez and Mazzon (2007).

This research has limitations. The sampling is a quota sampling, balancing between male and female. This sampling cannot be the representation of the entire population. Therefore, statistical generalization is not a strength of this research. Additionally, I have imbalanced classes. The percentages of technology choices are not well distributed.

However, this research can generalize to theory (theoretical generalization). Although the findings are not comprehensive, they serve as a starting point for theoretical development for technology selection theory. This research calls for a different theory for technology adoption from mainstream behavioral paradigms such as TPB, TAM, UTAUT1, and UTAUT2.

\section{Conclusion}

Thailand is transforming its economy into a digital economy. M-payment is a core technology that helps Thailand move from the real economy to the digital economy. However, researchers are curious about what factors influencing people to adopt mobile payment. Little literature focuses on users in Thailand. This study determines factors associating with the decision-making process in selecting an m-payment system of respondents: What do factors segregate m-payment adoption? 820 respondents were asked by using a questionnaire. SEM was employed to develop the measurement showing acceptable validity and reliability. I used multinomial logistic regression to classify technology choices. The results show low values of Pseudo R-Square, indicating that there is a lack of significant information from possible variables. The significant classifiers are age, income and the interactions between BI and ln (EXP), be- 
tween FC and age, and between FC and ln (EXP). Our research contribution is a statistical model for explaining the selection of different technology adoption. Predicting the use of completing technology adoption is different from traditional technology adoption research. Therefore, our study calls for a better theory in understanding the selection of TC.

\section{$7 \quad$ References}

[1] "Singapore, Thailand Weigh E-Payment Alliance in Digital Push," Bloomberg.com, 04-Oct-2017.

[2] Business Insider, "Thailand's national e-payment system should bolster ecommerce," Business Insider, 2016. http://www.businessinsider.com/thailands-nation al-e-payment-system-should-bolster-e-commerce-2016-7. [Accessed: 03-Mar-2018].

[3] Electronic Transactions Development Agency, "ETDA organizes Thailand eCommerce Week 2017; Push the Growth of Thais by e-Commerce, Maintaining ASEAN Championship - Toward to World Market," 2017. https://www.etda.or.th/ content/thailand-e-commerce-week-2017-press-conference.html. [Accessed: 03-Mar2018].

[4] Bank of Thailand, "Overview of payment system transactions," 2018. https://www. bot.or.th/Thai/Statistics/PaymentSystems/Pages/StatPaymentTransactions.aspx.[Accessed : 03-Mar-2018].

[5] A. S. Alhakami and P. Slovic, "A Psychological Study of the Inverse Relationship Between Perceived Risk and Perceived Benefit," Risk Anal., vol. 14, no. 6, pp. 1085-1096, Dec. 1994. https://doi.org/10.1111/j.1539-6924.1994.tb00080.x

[6] C. Flavián and M. Guinalíu, "Consumer trust, perceived security and privacy policy," Ind. Manag. Data Syst., vol. 106, no. 5, pp. 601-620, Jun. 2006. https://doi.org/10.1108/02635570610666403

[7] J. C. Roca, J. J. García, and J. J. de la Vega, "The importance of perceived trust, security and privacy in online trading systems," Inf. Manag. Comput. Secur., vol. 17, no. 2, pp. 96-113, Jun. 2009. https://doi.org/10.1108/09685220910963983

[8] T. Rakhi and S. Mala, "Adoption readiness, personal innovativeness, perceived risk and usage intention across customer groups for mobile payment services in India," Internet Res., vol. 24, no. 3, pp. 369-392, May 2014. https://doi.org/10. 1108/intr-12-2012-0244

[9] E. Bonsón Ponte, E. Carvajal-Trujillo, and T. Escobar-Rodríguez, "Influence of trust and perceived value on the intention to purchase travel online: Integrating the effects of assurance on trust antecedents," Tour. Manag., vol. 47, pp. 286302, Apr. 2015. https://doi.org/10.1016/j.tourman.2014.10.009

[10] Y. Yang, Y. Liu, H. Li, and B. Yu, "Understanding perceived risks in mobile payment acceptance," Ind. Manag. Data Syst., vol. 115, no. 2, 2015.

[11] Malik Khlaif Gharaibeh and Muhammad Rafie Mohd Arshad, "Using the UTAUT2 Model to Determine Factors Affecting Adoption of Mobile Banking Services: A Qualitative Approach," International Journal of Interactive Mobile Technologies (iJIM), vol. 12, no. 4, 2018. https://doi.org/10.3991/ijim.v12i4.8525 
[12] V. Venkatesh, J. Y. L. Thong, and X. Xu, "Consumer Acceptance and Use of Information Technology: Extending the Unified Theory of Acceptance and Use of Technology," MIS Q., vol. 36, pp. 157-178, 2012. https://doi.org/10.2307/41410412

[13] J. M. C. Hernandez and J. A. Mazzon, "Adoption of internet banking: proposition and implementation of an integrated methodology approach," Int. J. Bank Mark., vol. 25, no. 2, pp. 72-88, Mar. 2007. https://doi.org/10.1108/02652320710728410

[14] E. M. Rogers, Diffusion of Innovations, 3rd ed. New York: The Free Press, 1983.

[15] M. Fishbein and I. Ajzen, Predicting And Changing Behavior: The Reasoned Action Approach. New York: Psychology Press, 2010.

[16] F. D. Davis, R. P. Bagozzi, and P. R. Warshaw, "User Acceptance of Computer Technology: A Comparison of Two Theoretical Models," Manag. Sci., vol. 35, pp. 982-1003, 1989. https://doi.org/10.1287/mnsc.35.8.982

[17] V. Venkatesh, M. G. Morris, G. B. Davis, and F. D. Davis, "User Acceptance of Information Technology: Toward a Unified View," MIS Q., vol. 27, no. 3, pp. 425-478, 2003. https://doi.org/10.2307/30036540

[18] C. R. Plouffe, M. Vandenbosch, and J. Hulland, "Intermediating technologies and multi-group adoption: A comparison of consumer and merchant adoption intentions toward a new electronic payment system," J. Prod. Innov. Manag., vol. 18, no. 2, pp. 65-81, 2001. https://doi.org/10.1016/s0737-6782(00)00072-2

[19] T. Pikkarainen, K. Pikkarainen, H. Karjaluoto, and S. Pahnila, "Consumer acceptance of online banking: an extension of the technology acceptance model," Internet Res., vol. 14, no. 3, pp. 224-235, Jul. 2004. https://doi.org/10.1108/106622 $\underline{40410542652}$

[20] Khaled Aldiabat, Anwar Al-Gasaymeh, and Ameer Sardar Kwekha Rashid, "The Effect of Mobile Banking Application on Customer Interaction in the Jordanian Banking Industry," International Journal of Interactive Mobile Technologies (iJIM), vol. 13, no. 2, 2019. https://doi.org/10.3991/ijim.v13i02.9262

[21] L. Carter and F. Bélanger, "The utilization of e-government services: citizen trust, innovation and acceptance factors*," Inf. Syst. J., vol. 15, no. 1, pp. 5-25, 2005. https://doi.org/10.1111/j.1365-2575.2005.00183.x

[22] K. C. C. Yang, "Exploring factors affecting the adoption of mobile commerce in Singapore," Telemat. Inform., vol. 22, no. 3, pp. 257-277, Aug. 2005. https://doi. org/10.1016/j.tele.2004.11.003

[23] Sevgi Özkan, Gayani Bindusara, and Ray Hackney, "Facilitating the adoption of e-payment systems: theoretical constructs and empirical analysis," J. Enterp. Inf. Manag., vol. 23, no. 3, pp. 305-325, Apr. 2010. https://doi.org/10.1108/1741039101 $\underline{1036085}$

[24] Satwinderjit Singh, Izzal Asnira Zolkepli, and Cheah Wen Kit, "New Wave in Mobile Commerce Adoption via Mobile Applications in Malaysian Market: Investigating the Relationship Between Consumer Acceptance, Trust, and Self Efficacy," International Journal of Interactive Mobile Technologies (iJIM), vol. 12, no. 7, 2018. https://doi.org/10.3991/ijim.v12i7.8964

[25] R. K. Chellappa and P. A. Pavlou, "Perceived information security, financial liability and consumer trust in electronic commerce transactions," Logist. Inf. Manag., vol. 15, no. 5/6, pp. 358-368, Dec. 2002. https://doi.org/10.1108/095760 $\underline{50210447046}$ 
[26] M.-J. Kim, N. Chung, and C.-K. Lee, "The effect of perceived trust on electronic commerce: Shopping online for tourism products and services in South Korea," Tour. Manag., vol. 32, no. 2, pp. 256-265, Apr. 2011. https://doi.org/10.1016/j.tour man.2010.01.011

[27] H. Dai, X. (Robert) Luo, Q. Liao, and M. Cao, "Explaining consumer satisfaction of services: The role of innovativeness and emotion in an electronic mediated environment," Decis. Support Syst., vol. 70, pp. 97-106, Feb. 2015. https://doi.org/10. 1016/i.dss.2014.12.003

[28] W. D. Salisbury, R. A. Pearson, A. W. Pearson, and D. W. Miller, "Perceived security and World Wide Web purchase intention," Ind. Manag. Data Syst., vol. 101, no. 4, pp. 165-177, Jun. 2001. https://doi.org/10.1108/02635570110390071

[29] K. K. Kim and B. Prabhakar, "Initial Trust and the Adoption of B2C eCommerce: The Case of Internet Banking," SIGMIS Database, vol. 35, no. 2, pp. 50-64, Jun. 2004. https://doi.org/10.1145/1007965.1007970

[30] Y. Malhotra and D. F. Galletta, "Extending the Technology Acceptance Model to Account for Social Influence: Theoretical Base and Empirical Validation," presented at the 32nd Hawaii International Conference on System Sciences, 1999. https://doi.org/10.1109/hicss.1999.772658

[31] G. R. Maio and G. Haddock, The Psychology of Attitudes and Attitude Change. Thousand Oaks: SAGE Publications Inc., 2010.

[32] K.-Y. Lin and H.-P. Lu, "Why people use social networking sites: An empirical study integrating network externalities and motivation theory," Comput. Hum. Behav., vol. 27, pp. 1152-1161, 2011. https://doi.org/10.1016/j.chb.2010.12.009

[33] Y. Malhotra, D. F. Galletta, and L. J. Kirsch, "How Endogenous Motivations Influence User Intentions: Beyond the Dichotomy of Extrinsic and Intrinsic User Motivations," J. Manag. Inf. Syst., vol. 25, pp. 267-299, 2008. https://doi.org/10. 2753/mis0742-1222250110

[34] S. Taylor and P. A. Todd, "Understanding Information Technology Usage: A Test of Competing Models," Inf. Syst. Res., vol. 6, pp. 144-176, 1995.

[35] A. Raman and Y. Don, "Preservice Teachers' Acceptance of Learning Management Software: An Application of the UTAUT2 Model," Int. Educ. Stud., vol. 6, no. 7, p. p157, Jun. 2013. https://doi.org/10.5539/ies.v6n7p157

[36] O. Oechslein, M. Fleischmann, and T. Hess, "An Application of UTAUT2 on Social Recommender Systems: Incorporating Social Information for Performance Expectancy," in 2014 47th Hawaii International Conference on System Sciences (HICSS), 2014, pp. 3297-3306. https://doi.org/10.1109/hicss.2014.409

[37] F. J. Pascual-Miguel, Á. F. Agudo-Peregrina, and J. Chaparro-Peláez, "Influences of gender and product type on online purchasing," J. Bus. Res., vol. 68, no. 7, pp. 1550-1556, Jul. 2015. https://doi.org/10.1016/i.jbusres.2015.01.050

[38] G. Baptista and T. Oliveira, "Understanding mobile banking: The unified theory of acceptance and use of technology combined with cultural moderators," Comput. Hum. Behav., vol. 50, pp. 418-430, Sep. 2015. https://doi.org/10.1016/j.chb. 2015.04.024

[39] J. F. Hair, W. C. Black, B. J. Babin, and R. E. Anderson, Multivariate Data Analysis: A Global Perspective, 7th ed. Upper Saddle River, New Jersey: Pearson Prentice Hall, 2010. 


\section{Author}

Wornchanok Chaiyasoonthorn is an Assistant Professor at Faculty of Administration and Management, King Mongkut's Institute of Technology Ladkrabang. She has taught courses in management information systems and electronic commerce. She has researched areas of marketing, knowledge management, and technology adoption. Her current research interests are adoption behavior, organizational behavior, and technology management.

Article submitted 2019-05-09. Resubmitted 2019-06-29. Final acceptance 2019-07-10. Final version published as submitted by the authors. 